\title{
Teacher Role Analysis In Developing Communication And Collaboration Capabilities On Elementary Education Level
}

\author{
Yunisca Nurmalisa ${ }^{1}$, Elisa Seftriyana² \\ yunisca_nurmalisa@yahoo.com, elisaseftriyana09@gmail.com. \\ 1Departmen of Pancasila and Civic Education, Lampung University, Bandar Lampung, Lampung \\ 2Department of Civic Education, Universitas Pendidikan Indonesia, Bandung
}

\begin{abstract}
The purpose of this study was to analyze the role of the teacher in developing the ability to communicate and collaborate at the elementary school level in East Pringsewu. This study use a qualitative method by grounded theory design. Data analysis use interactive analysis by data reduction, data presentation, and data verification steps. The data credibility test uses techniques triangulation and source triangulation. The results of the study illustrated that teachers had a role that has not been effective in providing the ability to communicate and collaborate according to the demands of 21 st century competence. The role of teachers in the 21 st century has not been able to provide functional relationships that are able to construct, motivate, and track students' minds. The professional role of teachers that need to be developed can encourages learners to exchange ideas and provide verbal reinforcement related to their needs in carrying out communication and collaboration.
\end{abstract}

Keywords: Collaboration And Communication Skills, 21st Century Teacher Roles

\section{INTRODUCTION}

Education is an important instrument in improving the quality of human resources. The higher the demands of the times, the quality of education must increase. The development of the 21 st century world requires students to be able to compete and be able to face global demands. Learning success and success depends on achieving 21 st century competencies . 21 st century skills require the quality of students in IT skills (Information and Technology), social skills, and communication, problem solving, working together and thinking critically.

The quality of education in accordance with 21 st century competencies will be reflected in the learning process. Learning that refers to student activity in analyzing and compiling their own understanding based on their experience and knowledge or high order thinking skills (HOTS). HOTS based activities must be adapted to 21 st century competencies which are innovative, creative, critical, communicative, and collaborative.

Learning skills are acquired skills by an individual through an ongoing training process and include aspects of optimizing learning methods in the cognitive, affective or psychomotor domains. However, the main component of learning skills training in the concept of learning how to learn is focused on the individual himself as a learner, so that each individual is trained to develop his own learning characteristics and not be forced to follow a one-size learning style fits all (the same way to every one). Learning skills are believed to be more universal, which includes remembering facts, remembering concepts, remembering procedures, remembering principles, using concepts, using procedures, using principles, developing concepts, developing procedures, and developing principles.

In accordance with the graduates' competency standards, the dimensions of skills in basic education Have the skills to think and act creatively, productively, critically, independently, collaboratively, and communicatively through a scientific approach in accordance with the stages of 
child development that are relevant to the task given. Primary education aims to help students acquire the knowledge and skills they can use throughout their lives. In basic education, students not only learn academically, but also develop various skills and attitudes by means of planned activities and exercises. Skills development is important, especially communication and collaboration skills.

Teachers must have competent insights and abilities in applying communication and collaboration skills. Teachers must also be motivated to teach communication and collaboration knowledge and skills to overcome the challenges they face in their social lives. The development of these skills in line with PPKn learning competencies must be achieved holistically. The success of the civic skill mission and civic disposition is obtained because of the success of civic knowledge.

Communication and collaboration skills are in line with the new paradigm of learning Pancasila and Civic Education. The new paradigm of learning Pancasila and Civic Education, the teacher is the learning manager of the learning community in the classroom, the teacher conditions so that students actively communicate in their learning. The teacher helps students to understand the ideas of Pancasila and Civic Education correctly and rectify the understanding of students that are not appropriate (Qahar, 2011). Students learn Pancasila and Civic Education as if they are talking and writing about what they are doing. They are actively involved in carrying out classroom learning activities. Communication and collaboration skills in learning Pancasila and Civic Education are measured through the ability of students to express express ideas through writing, express ideas orally, conduct discussions, and draw conclusions from the results of the discussion or make decisions.

The teacher has the obligation to carry out the material with methods that support the success of achieving the learning outcomes. Class climate that is open to discussion is an important factor in strengthening citizenship insight and participation. The International Civic and Citizenship Study investigates the role of schooling in preparing students for their roles as citizens. Students civic knowledge scores are higher if in their school there is an open climate classroom discussion (Fabio Alivernini, Sara Manganelli, Procedia - Social and Behavioral Sciences, Volume 15, 2011, Pages 34413445. Communication and collaboration skills are one the ability that is expected to be obtained by students after learning Communication skills and collaboration of Pancasila and Civic Education is needed early through class learning so that students are able to interact and cooperate to solve problems. The importance of communication and collaboration skills must be supported by all components of learning including teachers. teacher's role in building communication and collaboration skills.

Formal education is a vehicle for gaining knowledge that is organized through the teaching and learning process. Formal education called schools carry out all activities planned regularly and directed at school education institutions (Suparlan Suhartono: 2008). As an effort to improve the quality of human resources, formal education through levels, namely basic education and secondary education. Basic education is early education as a basis for obtaining a level of knowledge that is adjusted to students' ability and development. Basically an educational institution that organizes a six-year education program for children aged 6-12 years (Suharjo: 2006, Fuad Ihsan: 2008).

Elementary schools usually serve children between the ages of five and eleven years, or kindergarten through sixth grade. Some elementary schools comprise kindergarten through fourth grade and are called primary schools. These schools are usually followed by a middle school, which includes fifth through eighth grades. Elementary schools can range from kindergarten to eighth grade (Harmon \& Jones: 2005). This opinion certainly leads to differences in basic education in several countries. The aim of basic education is to develop aspects of attitudes and skills. Basic education must be able to provide knowledge, build character by giving positive biases in learning and outside learning.

Pancasila and Civic Education have the aim, among others, to develop individual potential to become Indonesian citizens who are noble, intelligent, participatory, and responsible who need to be realized in daily life and are the demands of life for citizens in community life, nation and state as further elaboration of the ideas of values, concepts and morality of Pancasila, democratic citizenship, and 
defense of the state (Sunarso Dkk, 2008). Collaboration is important to foster mutual respect for responsibility, and care.

The XXI century has undergone a major transformation in the social, economic and political aspects of culture (Hargreaves, 2000) which is driven by four major strengths of mutual progress and technological change in demography, globalization and the environment. The advancement of internal information technology has increased learning in acquiring knowledge for every individual or student. Schools are urged to be superior and competitive and are faced with issues such as identity differences, rules of law, justice, social capital, and quality of life, and so on. Various environmental changes or crises that occur bring up the needs of school environmental education to increase sensitivity, awareness and responsibility of students towards the environment (Martin, 1999). XXI century professional teachers are teachers who are able to become learners throughout their careers to increase the effectiveness of student learning processes along with the development of the environment capable of working with learning.

There are several things that are important in the learning of this XXI century, pay attention to include the main task of the teacher as a learning planner, enter elements of higher order thinking, the application of varied approaches and learning models, and the most important technology integration is the teacher both who can develop an active and collaborative learning process, but of course the teacher must try to master the technology first (Trilling and Fadel, 2009).

21 st century competencies that students must possess include the ability to think innovatively, and creatively, think critically, communicatively and collaboratively. In the aspect of life skills to be able to be accepted is to be able to communicate and cooperate. This is a basic ability in carrying out community life, nation and state.

Communication in general is a relationship, in which communication implies an interaction. This interaction occurs because there is something that can be in the form of information or messages to be conveyed. Communication is a way of sharing ideas and classifying understanding. Through communication, ideas become objects of reflection, refinement, discussion, and reshuffle (Wahyudin, 2008). In the case of communication can be interpreted verbally and non verbally. The ability to communicate verbally becomes important. Communication activities are a component in collaboration. Collaboration itself is a form of social process, in which there are certain activities aimed at achieving common goals by helping each other and understanding each other's activities (Abdulsyani: 2011). Collaboration in learning involves the division of tasks, where each person does every work that is his responsibility for the achievement of common goals. In the broader concept, collaboration is carried out to achieve a common goal that has been established through the division of tasks / work, not as a work of deception but as a work unit, all of which are directed towards achieving goals.

\section{RESEARCH METHODS}

The purpose of this study was to analyze the role of the teacher in developing the ability to communicate and collaborate at the elementary school level in East Pringsewu. Research method used is a case study with qualitative approach. The research is conducted in SD Negeri 1 Pringsewu Timur. SD Negeri 1 Pringsewu Timur is a school with a facility category and low student intakes. The data collected through interview, observation and documentation were analyzed using Milles and Huberman model. The analyzing technique consists of data reduction, data presentation and data verification (Milles \& Haberman, 2012). The final data were validated using triangulation technique of data resources and collection technique.

\section{RESULT AND DISCUSSION}

Teachers are one of the factors of education that is very important, because education will lead students to maturity. Elementary School Teachers have tasks that are not light compared to other study 
subject teachers. This is because, in addition to delivering thematic and holistic subjects, which bring meaning to students' personality formation.

Teacher role indicators in developing communication and collaboration skills are divided into two, namely the role in developing verbal abilities and the role in motivating collaboration. Pringsewu 1 Public Elementary School is one of the elementary schools that has characteristics that make researchers want to see the role of teachers in developing aspects of communication and collaboration. The tasks of educators to develop students fully and optimally are actually a joint task that must be carried out by teachers, counselors, and labor. Meanwhile, each party still has a special service area in support of self-realization and achievement of student competence.

The success of learning activities can be supported by facilities and infrastructure, teacher competence, learning motivation of students. SD Negeri 1 Pringsewu can be said to have a low aspect in the three components. In the initial observation activity, the researchers found that the school facilities and infrastructure were far from adequate, the quantity and quality of the teacher's human resources were also very concerning where there were only 8 teachers, and the motivation of students who were less enthusiastic in teaching and learning activities. A deep analysis is looking at data showing that $87 \%$ are students from poor families. Some of these factors include researchers interested in seeing the role of teachers in developing communication and collaboration skills that are part of life skills that students must master.

In the interview activity, and communication which refers to teacher indicators can be used by teachers of SD Negeri 1 Pringsewu Timur. Always giving verbal reinforcement or appreciation for the courage of students. According to some teachers, building verbal responses that are displayed verbally or utterly to positive behavior. Verbal reinforcement in the form of expressions, gestures, student approaches, bait, and things that can please students. Giving back also has principles and ways of using or applying it in the learning process. Among others, to provide warmth and enthusiasm, meaningfulness, negative handling. How to apply it, among others, is connected to the person, to the group, together immediately, in use

Giving support seems simple and easy to apply but no longer exists. The advantages are like increasing or motivating students from the learning process, making students good and productive, making students active, and can improve students to learn independently. Students become bolder and confident in expressing opinions.

SD Negeri 1 Pringsewu Timur's teacher is able to develop learning strategies that provide opportunities for students to learn to work together. This is the meaning of the role and the teacher builds attitudes. The teacher always plays a role as a facilitator for students, they risk their time at school, by learning, discussing, organizing group tasks, reading, and doing other activities. The implementation of democratic education in the learning process in class certainly cannot be separated from the role of the teacher. The teacher must create a healthy atmosphere in the school to be a comfortable place for students to learn as much as possible. The right of students to help each other and exchange information they get from the results of access to information. Through discussion will foster democratic values because the implementation of the discussion is very similar to other students, learning to express their opinions, make opinions and not impose their opinions on others.

\section{CONCLUSION}

The teacher is a professional person who has the task to teach, educate and train students so that the goals can be maximized. Basic education on aspects of developing attitudes and skills. In the form of elementary school students who can be used to train. Pringsewu Timur 1 Elementary School Teachers Conduct learning activities in order to build communication and collaboration of students. The teacher always provides activities that build activities such as describing verbal reinforcement at all times of class discussions and presentations and providing assistance that brings good to students, both in terms of speaking or acting. Teachers can be used for example for their students. In addition, the 
teacher must instill character by determining, implementing, and familiarizing elementary school students to carry out activities that are in accordance with the expectations expected in the learning process. by maintaining that. So educating to arrange characters with good character can be replaced well.

\section{REFERENCE}

Abdulsyani. 2011. Studi Masyarakat Indonesia. Bandung: C.V. Maulana.

Bernie Trilling \& Charles Fadel. (2009). 21 st. Century Skills Learning for Life in Our Times. San

Fransisco: Wiley

Castetter, William. B. (1996). The Human Research for Educational. Administration. New Jersey

Ganratchakan Ninlawan. Factors which Affect Teachers' Professional Development in Teaching Innovation and Educational Technology in the 21st Century under the Bureau of Special Education, Office of the Basic Education Commission. Procedia - Social and Behavioral Sciences 197 ( 2015 ) 1732 - 1735.

Haag dan Keen. 1996. Information Technology: Tomorrow's Advantage Today. Hammond: Mcgraw-Hill College.

Martin.1999. Fundamental Information Analysis: An Extension and UK Evidence. British Accounting Review, Vol 31, No 3, September 1999

Miles, M. B. \& Huberman, A. M. (2012). Analisis Data Kualitatif: Buku Sumber Tentang Metode-Metode Baru. Jakarta: Universitas Indonesia Press.

Rasojo Diat Lantip, Riyanto, Teknologi Informasi Pendidikan Yogyakarta : Gava Media.

Robert L. Mathis - John H. Jackson. 2006. Human Resource Management, edisi 10,. Jakarta : Salemba Empat.

Roestiyah. 1994. Masalah Pengajaran Sebagai Suatu Sistem. Jakarta: Rineka Cipta.

Rudra P. Pradhan, Girijasankar Mallik, Tapan P. Bagchi. Information Communication Technology (ICT) Infrastructure And Economic Growth: A Causality Evinced By Cross-Country Panel Data. IIMB Management Review (2018) xx, 1-13

Wahyudin. 2008. Pembelajaran dan Model-model Pembelajaran. Bandung: UPI 